\title{
Interests, limits and possibilities of curricular structures in physical therapy
}

\author{
Interesses, limites e possibilidades das estruturas curriculares \\ na fisioterapia
}

\author{
Alberto Sumiya (iD [a], Dirce Shizuko Fujisawa (i) [b], Leila Marrach Basto de Albuquerque (iD [c]* \\ [a] Universidade Federal de Santa Catarina (UFSC), Curitibanos, SC, Brazil \\ [b] Universidade Estadual de Londrina (UEL), Londrina, PR, Brazil \\ [c] Universidade Estadual Paulista "Júlio de Mesquita Filho" (UNESP), Rio Claro, SP, Brazil
}

Abstract

Introduction: In Brazil, the field of physical therapy education has undergone transformations with regard to curricular models. However, changes require conscious, collective efforts to align multiple interests and achieve agreed goals, which usually do not occur without conflicts. Objective: To verify the tensions involving the curricular changes in a physical therapy course based on the concepts of field, habitus and capital of Pierre Bourdieu. Method: Qualitative study with field observation and interviews with teachers using a semi-structured script and content analysis. Results: Much internal resistance was observed, which prevented the process of change from expanding. Key disciplines were created with the aim to interconnect the curriculum matrix and favor content integration; however, these disciplines functioned, ultimately, like any other. Conclusion: Teachers continued to play by the rules of the field unaware of its determinations, that is,

*AS: PhD, e-mail: a.sumiya@ufsc.br

DSF: PhD, e-mail: dirce_fujisawa@uel.br

LMBA: PhD, e-mail: leilamarrach@uol.com.br 
the agents' habitus reflected the existing structure without changing the practices, and the discipline curriculum remained linear.

Keywords: Physical Therapy. Higher Education. Education. Curriculum. Social Sciences.

\section{Resumo}

Introdução: O campo da formação do fisioterapeuta no Brasil, em termos de modelos curriculares, tem passado por transformações. Contudo, mudar exige um esforço consciente e coletivo para alinhar múltiplos interesses e atingir as metas acordadas, o que geralmente não acontece sem conflitos. Objetivo: Verificar as tensões que envolvem as mudanças curriculares do um curso de fisioterapia, a partir dos conceitos de campo, habitus e capital de Pierre Bourdieu. Método: Pesquisa qualitativa com observações de campo e entrevistas com professores, utilizando roteiro semiestruturado e análise de conteúdo. Resultados: Houve muitas resistências internas que impediram que o processo de mudança fosse mais amplo. Criaram-se disciplinas-chaves que deveriam interligar a matriz favorecendo a integração de conteúdos, porém estas funcionavam, em última instância, como outras quaisquer. Conclusão: Os professores seguiram jogando com as regras do campo, sem saber das suas determinações, ou seja, os agentes e seus habitus refletiram a estrutura existente, sem alteração das práticas, permanecendo um currículo linear disciplinar.

Palavras-chave: Fisioterapia. Ensino Superior. Educação. Currículo. Ciências Sociais.

\section{Introduction}

Changes that occur in health education also include physical therapy, thus questioning of previously established structures is necessary. Changing requires many negotiation efforts to meet the myriad of interests that may arise from them. Consequently, curricular reforms are often conflicted because they reveal strategies and latent tensions. This study aims to examine the latest curricular change in the physical therapy course of the Universidade Estadual de Londrina (UEL) based on the concepts of field, habitus and capital constructed by Pierre Bourdieu - one of the most influential authors in the Social Sciences.

The field, in general, is configured as a space where social interactions occur. The field can be thought of as a football field with external demarcation and internal divisions where players (social agents) have positions with specific and relatively determined functions. Otherwise, the field is like a magnetic field, in which the lines of force that represent the agents and their power establish struggles to preserve or subvert positions, and thus define the hierarchies. Superiority legitimizes dominance, and power can be recognized through accumulated capital, which can be economic, cultural and social $[1,2]$.

The habitus focuses on ways of acting, feeling, thinking and being, capturing the history existing within the agents. When habitus is used analytically, it brings this history to the circumstances, pointing out the reasons for social regularities - these are the conditions and product of the field's functioning, adaptation and adjustment to the world. The agents express their habitus within the field - the incorporated provisions of the principles that generate and organize the practices and representations, which are mediated by the capital as process and product [1 - 3].

Thus, the relationship between the habitus and the field is one of conditioning/inculcation, as the field converges to the structuring of the habitus, causing the structure to become internalized. It turns out that the field acquires meaning and values for the agents through the capital, which is objectified as the habitus. Hence, Bourdieu states that the structure of the field is structured and structuring: [(habitus) $($ capital $)]+$ field $=$ practice. To that extent, when a change in the field, in this case it would be the field of physical therapy education, a reconfiguration of structure and order is intended, several situations are mobilized, triggering conflict between the agents, who expose their habitus, capital, and rules of the game for the fights $[1,3]$. 


\section{Method}

This study is part of a doctoral research on the hybrid character of physical therapy knowledge from the sociological categories of nature and culture, in which the researcher has been involved since his master's course. A qualitative methodology was used to approach the framework of structuralism [4 - 7], of which Bourdieu was representative. To this end, the physical therapy course of UEL was researched through the monitoring of seven teachers $[8,9]$ and their disciplines (Table 1) from March to June 2012.

Table 1 - Relationship between the UEL teachers and the disciplines they taught

\begin{tabular}{|c|c|c|}
\hline Teacher & $\begin{array}{l}\text { Discipline taught } \\
\text { (total credit hours) }\end{array}$ & Brief description of the syllabus \\
\hline BR-1 & $\begin{array}{l}\text { Scientific Research III } \\
\quad(\text { Annual }=60 \mathrm{~h})\end{array}$ & $\begin{array}{l}\text { Introduction to biostatistics, descriptive and inferential analysis, } \\
\text { use of statistical software, and their relationship with physical } \\
\text { therapy. }\end{array}$ \\
\hline $\begin{array}{l}\text { BR-2 } \\
\text { BR-3 }\end{array}$ & $\begin{array}{c}\text { Public Health II } \\
\text { (Semiannual = } 60 \text { h) }\end{array}$ & $\begin{array}{l}\text { Territory and coverage area of the Basic Health Unit. Analysis o } \\
\text { the health conditions of the population. The role of the physical } \\
\text { therapist. }\end{array}$ \\
\hline $\begin{array}{l}\text { BR-4 } \\
\text { BR-5 }\end{array}$ & $\begin{array}{l}\text { Interpersonal Skills I } \\
\text { (Annual = } 120 \mathrm{~h})\end{array}$ & $\begin{array}{l}\text { Introduction to physical therapy skills, with emphasis on } \\
\text { communication, reflective thinking, interpersonal relationships, } \\
\text { and body perception. }\end{array}$ \\
\hline $\begin{array}{l}\text { BR-6 } \\
\text { BR-7 }\end{array}$ & $\begin{array}{l}\text { Interpersonal Skills II } \\
(\text { Annual = } 150 \mathrm{~h})\end{array}$ & $\begin{array}{l}\text { Training in the use of physical therapy assessment resources } \\
\text { from different areas of expertise. }\end{array}$ \\
\hline
\end{tabular}

Semi-structured interviews with a script of 12 questions were also conducted with the teachers with no time limit. Content analysis [10] was used to treat the data, which enabled verification of the manifested messages through aggregation and classification that resulted in classification by categories [11].

The choice of the observed disciplines is justified by the centrality they assumed during the master's research, firstly, because they would function as vertical axes (covering different grades/years) to promote content integration within the curriculum matrix; secondly, because they could represent the starting points for new ways of teaching. Therefore, they are expressive examples of tensions in the field of physical therapy education.

The research project was appraised and approved by the Research Ethics Committee of the Universidade Estadual do Centro-Oeste (UNICENTRO-PR) under protocol n. 486/2011. This study was financed in part by the Coordenação de Aperfeiçoamento de Pessoal de Nível Superior - Brasil (CAPES) — Finance Code 001.

\section{Results}

The original doctoral research produced three categories of analysis, namely, professional profile, field of power, and curricular integration. The focus of this study is the second category, whose signs and meanings reveal, without the intention of being a finished view, a little of the structure of the field of physical therapy and its relations with regard to curricular changes. Aiming to favor the understanding of this category, the observed disciplines will be briefly described, remembering that they were substrates for the interviews, which are included in the discussion, seeking the concrete totality that is proposed for the structural analysis (Figure 1).

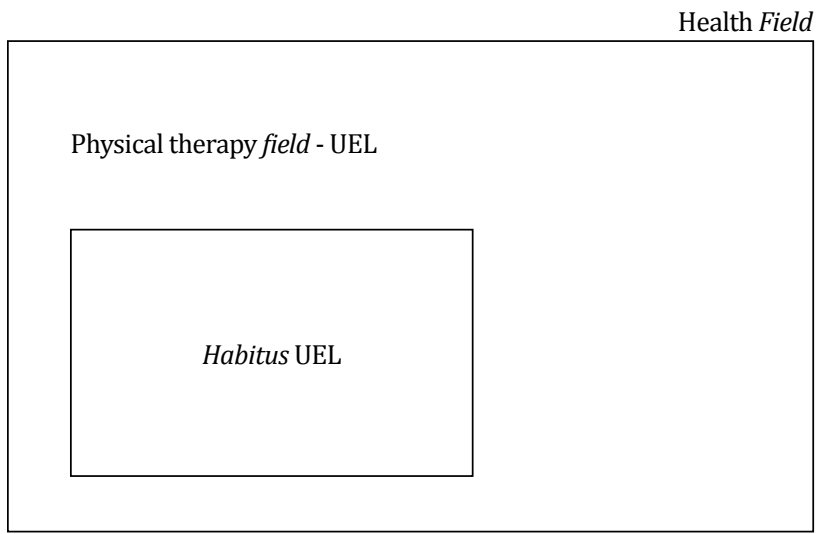

Figure 1 - Structural analysis. 
The physical therapy course of UEL

The UEL implemented the first physical therapy course of the state of Paraná in the second semester of 1979. The course was approved through Ordinance no. 11,365 and was administered by the Department of Internal Medicine. At that time, the course had duration of three years and a total of 2,655 credit hours, a credit enrollment system, and a curriculum composed of basic, applied and internship disciplines. The Department of Physical Therapy was created on April 13, 1983.

In 1985, through Resolution no. 4/83, the first curricular change occurred, and the course was expanded from three to four academic years, with disciplines divided into cycles with a workload of 4,038 h. The 1985 curriculum remained unchanged until 1992, when the Department of Physical Therapy changed the semiannual credit enrollment system to an annual system. The third change occurred in 2006, with knowledge divided into axes and the workload was raised to $4,832 \mathrm{~h}$, with $5 \%$ of it intended to complementary academic activities.

The Course Pedagogical Project (PPC) reflects the National Curriculum Guidelines (DCN) for physical therapy courses based on five knowledge axes: Social and Human Sciences, Biotechnological Knowledge, Biological and Health Sciences, and Physical Therapy Knowledge, representing 7.50, 5.30, 18.70 and 68.50 of the total credit hours, respectively.

The curriculum matrix is subdivided into series with annual and/or semiannual disciplines. Course completion can be achieved in at least four years through theoretical and practical classes and mandatory supervised placement, with lectures as the main teaching method. In the analysis of the syllabi of the disciplines selected in this study and of their developments (II and/or III), there was no direct written mention of connection showing any aspect of continuity, resumption and/or rescue of content for the construction of new knowledge. In general, the UEL physical therapy curriculum presents the best-known organization configuration, that is, a model that can be called traditional.

\section{On field observations}

All fieldwork was conducted smoothly, and the teachers were collaborative. The disciplines were monitored until a saturation point was found, which was based on the repetition of the speeches in relation to the approached theory. There were conversations inside and outside the classroom, including with students, which served as indirect means of complementing information.

Scientific Research III was characterized as a traditional discipline, predominantly using expository methodologies, centered on the teacher and with assessment by exams, which is in accordance with the professional profile of its teacher, and the students recognize and respect his authority for his widely known trajectory as a researcher and graduate studies adviser, as well as for his publications, and mainly for this specific physical therapy area, which is considered difficult. Naturally, evidencebased practice is advocated, and techniques aimed at serving the market are criticized. Concerning the curricular change, dissatisfaction was expressed with the reduction of the workloads of the existing internships, mainly with the inclusion of the placement in Public Health, which brought the sense of curricular swelling, thus impairing the monitoring and evolution of treatments.

Public Health II is a discipline taught through a mixing of active and traditional methodologies and is under the responsibility of four teachers - not all of them specialized in the area. The students were interested and occasionally confused, as they had difficulty understanding how to apply the concepts in practice, which generated a sense of unease. The teachers reported that this discipline is little sought for graduate studies, and that students prefer to focus on neurology, pulmonology and orthopedics, which are consolidated specialties.

Interpersonal Skills I is a discipline headed by four teachers. The classes are developed more with group dynamics and discussions with the purpose to prepare/introduce the students to other contents. In the context of UEL, relatively innovative themes are taught, which according to teachers demand more preparation and tuning from those involved. A certain difficulty in dealing with references from the Human and Social Sciences that permeate the discipline was observed. The complaint is that the fundamentals taught do not have continuity or repercussion in the curriculum matrix. A priori, this discipline would be the flagship of a major change.

Interpersonal Skills II is a discipline also headed by four teachers; one of them is responsible only for 
the theoretical part, whereas the others are in charge of the practical classes. The class is very active, but not very committed. The discipline is treated in a very objective way in the theoretical part, focusing more on know-how. As for practice, standardized scripts are used showing a concern of the teachers to be aligned with the same language and technique. However, they showed little personal affinity, which may be associated with their areas of origin, which were different from that of this discipline. The discipline was explicitly classified as simple and/or basic in theory.

\section{Discussion}

According to Santomé [12], the linear disciplinary model is the most traditional way of organizing content within a curricular matrix. This model aims to achieve classifications, providing concreteness to the representation of experience in disciplines. However, this traditional configuration is criticized for presenting itself as a "puzzle" curriculum, because the contents are isolated, fragmented and, sometimes, restricted within a closed structure. Thus, the structure used in disciplines, the curriculum matrix, may even be easy to manage, but is difficult to operationalize in the construction of knowledge, which is not autonomous and thus requires the understanding of relationships with other more complex dimensions of reality.

According to Lopes and Macedo [13], the curriculum development model that has predominantly influenced Brazil is the linear disciplinary model, focused on the legacy of technology and efficiency [14]. Specifically, the organization of academic experiences would occur horizontally between the study areas, and time would be the vertical component of this perspective, which involves the principles of continuity, sequence and integration of contents. The first two principles are responsible for the subsequent resumption of experiences, and integration would occur in the same curricular phase [13].

From these theoretical frameworks, it was possible to observe that the curriculum of the course herein analyzed fits into the traditional linear model. As previously mentioned, the new disciplines sought to improve content integration vertically, differently from what was proposed by Lopes and Macedo [13], but aligned with the idea of a spiral curriculum [15], which intends to visit themes interactively, avoiding repetitions but based on constant reinforcement of the contents, moving from the simple to the complex in logical and flexible sequences, always stimulating students to exceed the objectives, gaining in breadth and depth of knowledge.

Thus, analysis of the UEL physical therapy course revealed a paradoxical curricular project, in the sense that the traditional curriculum does not fit perfectly in the objective of curricular integration, as it does not seek to categorize academic activities in the disciplines [16]. According to Beane's theory [16], the new disciplines of the UEL physical therapy course should play the role of organizing centers and/or contexts to unify knowledge in an already integrated curriculum. Thus, circumscribed to a traditional curriculum, the axes that the UEL disciplines should establish were dimmed, and according to the interviewed teachers they did not go beyond the idea that they were just disciplines like any other. In general, it could be understood that the agents with their capital opted for maintaining the structured structure.

The field concept then enables associating the structure with its functioning, explaining the social relationships and hierarchical positions of the agents, as well as the competitions and interests to be disputed, so that changes can be carried out or avoided. The strategies are then used in practices of winning, remembering that they are guided by the habitus and the capital. The set of these factors is interpreted as a potential of the virtues, aspirations and investment trajectory to determine the right to stay in or enter the field [17 - 20].

In this context, the tensions generated by the curricular reformulation serve to scrutinize the agents' autonomies. Within the scope of the Health Sciences Center of UEL, the reformulations began with the reorientation of training for the Unified Health System (SUS) [21], then with the adherence to the UNI Project [22], and influenced by the National Education Guidelines and Framework Law (LDB) of 1996 and new teachinglearning methodologies. In the case of physical therapy, it culminates with the National Curricular Guidelines (DCN) for physical therapy courses [23], which are still undergoing reformulation.

In addition to the historical character previously evidenced, it is important to preliminarily establish the conflicting character involving the curricular changes of the UEL physical therapy course, which were found to be unsatisfactory and permeated by resistance from teachers:

It was very hard work, but I think there is lack of adherence to the philosophy of this change entirely. 
Knowing that you have to change does not mean that you are changing (BR-5).

My dissatisfaction is not with the curriculum. It is with the lack of involvement of some teachers, who do not want to change their day-to-day practices at all (BR-6).

You can even participate in meetings, discussions, and assemblies, but you will not allow these changes to occur (BR-1).

In this sense, based on Bourdieu's concepts, the presence of regularities can be recognized, that is, lack of adherence to curricular changes is not uncommon, as described by Teixeira [24], especially when they are usually led by committees, insofar as those who not directly linked to the process of change end up not agreeing with the new project and its goals, implying asynchrony in the collective work [25].

However, Bourdieu [1] advocated that the oppositions themselves support the game and the language that is used in it, hence resistance cannot be reduced. It would be the so-called interested disinterest aiming to maintain the order [26]; therefore, regardless of what the interests are, these are legitimate because "the cultured men of a particular time may disagree about the objects they dispute, but are at least in agreement to dispute certain objects" [2] — consensus within dissensus.

Consequently, those who reach the top of the hierarchy have the right to dominance, exercising it as a political function to strengthen their own culture, thus defining themselves by the distance from the subcultures of the dominated, which have a lower degree of autonomy/ independence, as indicated the excerpt ahead:

I joke with the students: - Who is fancy, guys? Who are the physical therapists with the highest status nowadays? - The pulmonary therapists, we believe. Everyone said. They want to work in an ICU with technology. It's not fancy to be a physical therapist in an outpatient clinic, is it? Nobody wants to be physical therapist at SUS (BR-2).

Pereira Neto [27] informs that, currently, professional practice is largely based on intense technology, which confers significant prestige. This question can be translated in terms of having recognition (acquired more readily) and credibility (obtained over time) [28].
For Bourdieu [29], subverting a previously established order demands agents to accumulate more capital to construct a name from scratch.

This cannot be easily achieved, because it requires a reserve of recognition and credibility, such as the Supervised Placement in Physical Therapy in Public Health at UEL, which had to dispute a position with the pre-existing forces of the field, having external pressures as drivers: the DCN [23] and the need to associate SUS with training:

There was a fight in the department. In fact, the creation of the Public Health Placement was a forceps delivery, because people still do not value it, even within the department and, to make matters worse, to create another internship, the hours of all the others had to be reduced. [...] This ends up even affecting the students' view (BR-3).

This area has grown a lot. It has grown suddenly. It has gown in terms of workload. There were sectors that already intended to have this workload. If we want to have placement in this sector, the other placements end up losing. Whether you like it or not, you create a new placement field, reduce the number of students for attendance, which was already overloaded. We were the Public Health team fighting for the Public Health Placement. The others either did not say anything or were radically against it (BR-2).

In fact, internship was the tensest topic of the interviews, which raised latent disagreements. The teachers' representations about placement are positive, as the key element of the training, the strength of the curriculum, the moment of deepening, the transition to the market, and the consolidation of a professional identity. Because it is so important, these representations were also accompanied by concerns, complaints, and criticism:

Time in the specialties of placement, I consider it little, since in my conception, the sophomore year is what enables the senior year, which is placement, and is very technical, very qualified, very tied up; students go to the field for two months, sometimes for less than two months, and is insufficient. At least to provide students the opportunity to develop, put into practice skills that are very complex, then they close the cycle. Maybe we will become, thinking about my internship, my relationship with the students, we will become very 
conservative again, very technical again, so that maybe we won't suffer much (BR-4).

[...] I need time to have training, training is repetitions and news arising from and leaving these situations, so training time, extremely shorter, six weeks of in-service training for education, I think it is a sin. I'll say it again, the equal division for the unequal, the poor conduction of certain placements, public health nowadays, I've already said that, and I was also stoned. In public health, I can't make visits, it is not my job, to visit the individual who is lying in bed, full of deformity, to want to do something for him, to go there to assist, this is not the current notion of public health, I have to have my prevention programs, I have to have my groups of hypertensive patients, I have to have my educational groups, pay visits to assist is the responsibility of the city hall, it is the function of the contractor, this is the function of health network physical therapists, this is the function of social service, to go there and assist the people full of deformities, take them to rehabilitation, take them to treatment, that's why some internships are poorly conducted (BR-1).

From these reports, it is first understood that BR4 , a teacher of the Skills discipline, perceives a rupture between the knowledge built in the freshman year and the supervised internship, something that was lostalong the way and that indirectly questions the reality of the change made. Second, the seemingly dysfunctional tendencies in the field, such as refusal to cooperate, are inscribed in the mechanisms that give rise to the most functional provisions, so without being fully aware of their determinations, the agents play the game of opposition and complementarity (illusio) [30] in which "the manifest conflicts between tendencies and doctrines conceal, in the very eyes of those engaged in them, the complicity that they suppose and that surprises the observerforeign to the system" [2]. Furthermore, it was also revealed, through a discourse of judgment and disapproval, how an agent (BR-1) with more capital [31, 32] exercises its habitus, referring again to the question of the interests of the position: "there is no judge who is not, at the same time, judge and interested party" [29].

In general, what the analysis of curricular changes at UEL shows is the tendency to fight for the perpetuation/reproduction of the structure of the existing field, as they reinforce:
I'll tell you one thing, I, along with the teachers here, have gone through several moments of curriculum change and reformulation, so nowadays, I believe that, when we made the choice, not that of a complete change in the curriculum, but, in other words, a curricular restructuring, a curricular reformulation, which was the department's option, I think it was a very wise choice [...] If there were a radical change, if it were a radical change, we might not have had the results we have nowadays, so these adjustments and this partial change, I mean partial, because it was partial, I think it provides us with the opportunity to make this continuous adjustment in the curriculum (BR-7).

I can see that there is a perfect possibility of having good practical training and good theoretical training, but unfortunately, there is change, there is change, there is change, curriculum reform, curriculum reform, you trade six of one for half a dozen of the other (BR-1).

The statements of these teachers are of denunciation, but they are also of resistance to change, because there is no real need. Are the expected changes, then, doomed to adaptations only? Could there be a way to escape determinism and reproduction mechanisms? What does the inclusion of new disciplines in the curriculum mean?

The answers to these questions end up, together, forming the analytical totality expected in the structuralist proposal of this study. Bourdieu [1, 2, 4] explains that the conditions of the field vary with time and history, which serves to understand its contemporary form, which directly announces the concept of habitus as continuously adaptable. When there is a mismatch between changes in the structure of the field in relation to changes in the dispositions of the agents, this is called hysteresis - this disjunction is what allows the agents to experience the feeling of change. It is worth noting that hysteresis with inertia of the habitus offers opportunities for those who already experience success to guarantee it even more, while the less successful ones would remain unaware of the strengths and weaknesses of their positions in the field [33].

Based on Bourdieu's theory [1 - 3, 17, 29, 32, 34], if the intention is to overcome the deterministic character of the structure in order to achieve change, then revolution with the elimination of the old structure would be necessary, this could be considered the real change. Those with less capital are left with the task 
of recognizing and identifying the properties of the structure (of the conditioning forces), which allowed the organization and the planning to remove them with the struggle.

Consequently, the new disciplines represented only minor adaptations, which were driven by external pressures, which Bourdieu [29, 34 - 36] would classify as symbolic violence (interference with the established internal dynamics of the field). In summary, again based on Bourdieu [1 - 3, 17, 29, 32, 34], it can be understood that what was called change by teachers, was not sufficient to establish a new structure for the field, which was also confirmed by maintaining the habitus; otherwise, the previous curricular conformation prevailed - social reproduction.

\section{Conclusion}

Change puts the field in motion and materializes the game of the interests underlying the desire to maintain the existing structure, thus triggering conflicts and competitions to define the control of the internal reproduction mechanisms. This analysis evidenced the rules of the field and the habitus of the sense of the game, both expressed when the teachers fought for the change or permanence of the existing structure with their capital, resulting in a linear disciplinary curriculum, historically similar to all previous models of the course.

Punctually, the desire for change brought about the need to read just the credit hours, giving rise to confrontation, especially for the teachers involved in Public Health, who were criticized by opponents who did not recognize the area as consolidated at the time. Interpersonal Skills I, which worked with more contemporary teaching-learning perspectives, naturally became the flagship of change, but failed to propagate the principles that would guarantee content integration, even among its developments. Interpersonal Skills II was a portrait of this situation; this discipline was permeated with internal strife and lack of harmony, having no connection with Interpersonal Skills I. Scientific Research III remained in the comfort zone, because it was led by a single teacher, and thus function without interference.

The present study, which was based on Bourdieu's knowledge, demonstrated that change does not really occur if the rules and the positions occupied remain the same. The dominance structure can adapt to different contexts, without necessarily changing its essence. In the case of the analyzed physical therapy course, it was possible to observe that the structure logic still in force at the time prevailed. In addition, the proposal of content integration was not compatible with the traditional operationalization of the curriculum matrix. In conclusion, the structure of the field did not conform to change. The agents with the largest capital supported their positions and reproduced the same habitus. Nevertheless, it is of great importance for health courses to know other theoretical frameworks, to unveil the obstacles that hinder the realization of change processes.

\section{References}

1. Bourdieu P. A gênese dos conceitos de habitus e de campo. In: O poder simbólico. $3^{\text {rd }}$ ed. Rio de Janeiro: Bertrand Brasil; 2000. p. 59-73.

2. Bourdieu P. Campo intelectual e projeto criador. In: Pouillon J (Org.). Problemas do estruturalismo. Rio de Janeiro: Zahar, 1968. p. 105-5.

3. Bourdieu P. Campo do poder, campo intelectual e habitus de classe. In: Miceli S, Miceli S (Org.). A economia das trocas simbólicas. $6^{\text {th }}$. São Paulo: Perspectiva; 2005. p. 183-202.

4. Misoczky MCA. Implicações do uso das formulações sobre campo de poder e ação de Bourdieu nos estudos organizacionais. Rev Adm Contemp. 2003;7(n.spe):9-30.

5. Thiry-Cherques HR. O primeiro estruturalismo: método de pesquisa para as ciências da gestão. Rev Adm Contemp. 2006;10(2):137-56.

6. Souza Neto AF, Mello SCB. Olhando além do "primeiro estruturalismo" para a pesquisa em marketing. Rev Adm Contemp. 2009;13(4):525-44.

7. Gomes AP, Rego S. Pierre Bourdieu e formação médica. Rev Bras Educ Med. 2013;37(2):260-5.

8. Silva HRS. A situação etnográfica: andar e ver. Horiz Antropol. 2009;15(32):171-88.

9. Nakamura E. O método etnográfico em pesquisas na área da saúde: uma reflexão antropológica. Saude Soc. 2011;20(1):95-103.

10. Bardin L. Análise de conteúdo. Lisboa: Edições 70; 2010.

11. Hsieh HF, Shannon SE. Three Approaches to qualitative Content Analysis. Qual Health Res. 2005;15(9):1277-88. 
12. SantoméJT. Globalização e interdisciplinaridade: o currículo integrado. Porto Alegre: Ed. Artes Médicas Sul Ltda;1998.

13. Lopes AC, Macedo E. Teorias de currículo. São Paulo: Cortez; 2011.

14. Sacristán JG. 0 curriculo: uma reflexão sobre a prática. $3^{\text {rd }}$ ed. Porto Alegre: Artmed; 2000.

15. Harden RM, Stamper N. What is a spiral curriculum? Med Teach. 1999;21(2):141-3.

16. Beane JA. Integração curricular: A essência de uma escola democrática. Currículo Sem Fronteiras. 2003;3(2):91-110.

17. Bourdieu P. Questões de sociologia.Lisboa: Fim deSéculo; 2003. p. 119-26.

18. Thiry-Cherques HR. Pierre Bourdieu: a teoria na prática. Rev Adm Publica. 2006b;40(1):27-55.

19. Montagner MA, Montagner MI. teoria geral dos campos de Pierre Bourdieu: uma leitura. Tempus, Actas de Saude Col. 2011;5(2):255-73.

20. Bonnewitz P. Primeiras lições sobre a sociologia de P. Bourdieu. Rio de Janeiro: Petrópolis; 2003.

21. Brasil. Lei 8080 de 19 de setembro de 1990. Dispõe sobre as condições para a promoção, proteção e recuperação da saúde, a organização e o funcionamento dos serviços correspondentes e dá outras providências. Brasília: Diário Oficial da União; 1990 Set 20.

22. Machado JLM. Uma nova iniciativa na formação dos profissionais de saúde. Interface. 1997;1(1):147-56.

23. Brasil. Resolução CNE/CES 4 - Diretrizes Curriculares Nacionais do Curso de Graduação em Fisioterapia. Brasília: Diário Oficial da União; 2002 Mar 4.
24. Teixeira RC. Aderência dos cursos de fisioterapia da região norte às diretrizes curriculares nacionais. Fisioter Mov. 2012;25(1):47-54.

25. Rios IC, Lopes Jr A, Kaufman A, Viera JE, Scanavino MT, Oliveira RA. A integração das disciplinas de humanidades médicas na faculdade de medicina da USP - um caminho para o ensino. Rev Bras Educ Med. 2008;32(1);112-21.

26. Merton RK. El efecto Mateo en la ciencia. In: La sociologia de la ciencia. $2^{\text {nd }}$ ed. Madrid: Alianza; 1977.

27. Pereira Neto AF. Tornar-se cientista: o ponto de vista de Bruno Latour. Cad Saude Publica. 1997;13(1):109-18.

28. Latour B, Woolgar S. Vida de laboratório - a produção dos fatos científicos. Rio de Janeiro: Relume Dumará; 1997.

29. Ortiz R(Org.). Pierre Bourdieu: sociologia. São Paulo: Ática; 1983.

30. Catani AM, Nogueira MA, Hey AP, Medeiros CCC (Orgs.). Vocabulário Bourdieu. Belo Horizonte: Autêntica; 2017.

31. Garcia MMA. 0 campo das produções simbólicas e o campo científico em Bourdieu. Cad Pesq. 1992;97:64-72.

32. Bourdieu P. Homo academicus. Standford: Standford University Press; 1988.

33. Grenfell M. Pierre Bourdieu: conceitos fundamentais. Petrópolis: Vozes; 2018.

34. Bourdieu P. Os usos sociais da ciência: por uma sociologia clínica do campo científico. São Paulo: EditoraUNESP; 2004.

35. Grenfell M, James D. Change in the field - changing the field: Bourdieu and the methodological practice of education research. British Journal of Sociology of Education. 2004; 25(4):507-23.

36. Freitas C. A prática em Bourdieu. Rev Cient FacMais. 2012;1(1):1-18.
Received: $10 / 31 / 2018$

Recebido: 31/10/2018

Approved: 02/03/2020

Aprovado: 03/02/2020 